\title{
Hubungan Fanatisme Kelompok dengan Perilaku Agresi pada Anggota Organisasi Kemasyarakatan
}

\author{
Ida Bagus Putu Raden Raditya Manuaba dan Supriyadi \\ Program Studi Psikologi, Fakultas Kedokteran, Universitas Udayana \\ dita.raden@gmail.com
}

\begin{abstract}
Abstrak
Organisasi masyarakat merupakan sebuah lembaga kemasyarakatan yang didirikan dan dibentuk oleh masyarakat secara sukarela berdasarkan kesamaan aspirasi, kehendak, kebutuhan, kepentingan, kegiatan dan memiliki tujuan untuk berpartisipasi dalam pembangunan demi tercapainya tujuan Negara Kesatuan Republik Indonesia yang berdasarkan Pancasila. Fanatisme digambarkan sebagai suatu kepatuhan penuh gairah tanpa syarat, antusiasme yang berlebihan terhadap suatu hal tertentu, keras kepala, tanpa pandang bulu atau menggunakan cara-cara dengan kekerasan, fanatisme juga ditandai dengan adanya pemikiran dogmatis, tidak memiliki toleransi terhadap perbedaan dan keinginan untuk memaksakan pandangan secara sepihak, rasa harga diri meningkat dan merasa berkuasa, sehingga mendorong terjadinya perilaku agresi. Banyak organisasi masyarakat yang tumbuh dan berkembang di Bali dengan berbagai latar belakang pemikiran yang berbeda-beda. Fakta di lapangan sering menimbulkan berbagai macam gesekan. Akhir-akhir ini terjadi beberapa kasus kekerasan yang dilakukan oleh sejumlah anggota organisasi kemasyarakatan di Bali sehingga menimbulkan keresahan-keresahan di masyarakat. Penelitian ini bertujuan untuk mengetahui hubungan fanatisme kelompok dengan perilaku agresi. Dalam penelitian ini tidak menggunakan seluruh anggota populasi. Subjek yang digunakan dalam penelitian ini adalah anggota organisasi kemasyarakatan Laskar Bali Koordinator lapangan Alas Kedaton yang berusia 18 hingga 55 tahun serta minimal sudah menjadi anggota selama satu tahun. Jumlah sampel pada penelitian ini adalah 62 orang. Reliabilitas skala fanatisme kelompok adalah 0.839 dan reliabilitas skala perilaku agresi adalah 0.917. Metode analisis yang digunakan adalah analisis korelasi Spearman, kerena dari uji Kolmogorov-Smirnov sebaran data tidak menunnjukkan distribusi normal. Hasil uji korelasi dalam penelitian ini adalah 0,356 p>0,05. Berdasarkan hasil penelitian dapat disimpulkan tidak ada hubungan antara fanatisme kelompok dengan perilaku agresi pada anggota organisasi kemasyarakatan Laskar Bali koordinator lapangan Alas Kedaton.
\end{abstract}

Kata kunci: Fanatisme kelompok, Perilaku agresi, Anggota organisasi kemasyarakatan

\begin{abstract}
Community organization is a civil organization that was founded and formed by public voluntarily based on the similarity of the will, aspirations, needs, interest, activities and same purposes to participate in development to achive the purpose of Unitary States of Indonesia based on Pancasila. Fanaticism is potrayed as a passionate compliance without conditions, excessive enthusiasm of a certain thing, stubborn, indiscriminately or use means of violence, fanaticism is also characterized by the presence of dogmatic thinking, have no tolerance of differences and the desire to impose unilateral view, increased sense of self-worth and feel powerful which is encourage aggression behaviour. In Bali, there is large number of civil organizations grow and develop with different backgrounds, which is often cause some friction. Lately in some case of violence carried out by a number of members of those civil organization in Bali, make some anxiety in the society. This research aims to know the relationship of group fanaticism with behaviour of aggression. This research did not use all member from the population. Subject in this research is a members of civil organization called Laskar Bali, Alas Kedaton, with age from 18 years old to 55 years old and at least have been member for minimum one year. Number of samples in this research was 62 peoples. Reliabillity scale of group fanaticism is 0,839 and aggression behaviour scale reliabillity is 0.917 . Analysis method use Spearman correlation test. Correlation test result 0.356 which mean $p>0.05$. So based on the result of this research there is no relations between group fanaticism and aggression behaviour on civil organization members at Laskar Bali, area coordinator Alas Kedaton.
\end{abstract}

Keywords: Group fanaticism, Aggression behaviour, Civil organization member 


\section{LATAR BELAKANG}

Organisasi masyarakat merupakan sebuah lembaga kemasyarakatan yang menurut Undang-Undang Nomor 17 Tahun 2013 Tentang Organisasi Kemasyarakatan, menyebutkan bahwa organisasi kemasyarakatan adalah organisasi yang didirikan dan dibentuk oleh masyarakat secara sukarela berdasarkan kesamaan aspirasi, kehendak, kebutuhan, kepentingan, kegiatan dan memiliki tujuan untuk berpartisipasi dalam pembangunan demi tercapainya tujuan Negara Kesatuan Republik Indonesia yang berdasarkan Pancasila. Menurut Manuaba (2014) pada dasarnya keberadaan organisasi kemasyarakatan dapat sangat membantu negara dalam menjalankan nilai-nilai dan keikutsertaan masyarakat dalam menegakkan nilai-nilai Pancasila yang merupakan dasar negara.

Undang-Undang Republik Indonesia Nomor 8 tahun 1985 Tentang Organisasi Kemasyarakatan juga menyebut jika organisasi kemasyarakatan selain berfungsi sebagai sarana untuk menyalurkan pendapat dan pikiran bagi warga negara Republik Indonesia juga mempunyai peranan yang sangat penting dalam meningkatkan keikutsertaan seluruh lapisan masyarakat agar aktif dalam mewujudkan masyarakat Pancasila berdasarkan Undang-Undang Dasar negara Republik Indonesia Tahun 1945. Menurut Manuaba (2014) maka secara pengertian dan fungsi keberadaan organisasi kemasyarakatan sangatlah penting untuk menunjang implementasi dari nilainilai Pancasila dalam rangka menjamin pemantapan persatuan dan kesatuan bangsa, menjamin keberhasilan pembangunan nasional sebagai pengamalan Pancasila, sekaligus menjamin tercapainya tujuan nasional.

Menurut Suyono (2013), jumlah organisasi kemasyarakatan yang ada di Indonesia sangat banyak, tercatat ada 139.957 organisasi kemasyarakatan dengan rincian 65.577 organisasi kemasyarakatan dibawah kendali Kemendagri (Kementerian Dalam Negeri), 25.406 organisasi kemasyarakatan dibawah kendali Kemsos (Kementerian Sosial), 48.866 organisasi kemasyarakatan dibawah kendali Kemenkumham (Kementerian Hukum dan Hak Asasi Manusia) serta terdapat juga 108 organisasi kemasyarakatan asing dibawah kendali Kemlu (Kementerian Luar Negeri). Khusus pada provinsi Bali, data yang diperoleh dari Badan Kesbangpol (Kesatuan Bangsa dan Politik) provinsi Bali, jumlah organisasi kemasyarakatan yang sudah terdaftar adalah 996 organisasi kemasyarakatan, jumlah tersebut tidak termasuk organisasi kemasyarakatan yang belum terdaftar atau sudah tidak aktif lagi sesuai bank data yang dimiliki Kesbangpol provinsi Bali (Isa, 2013).

Semakin besar jumlah organisasi kemasyarakatan maka ideologi atau nilai-nilai yang diajarkan oleh organisasi kemasyarakatan dan diadopsi oleh masyarakat akan semakin banyak sehingga rentan menimbulkan gesekan-gesekan yang dapat memicu munculnya pertikaian antar organisasi kemasyarakatan, terlebih bagi organisasi kemasyarakatan garis keras yang anggotanya cenderung bersifat fanatik (Manuaba, 2014). Bidang-bidang fokus dari pada organisasi kemasyarakatan ini juga sangat beragam mulai dari bidang keamanan, politik, hak asasi manusia, perlindungan wanita dan anak hingga kesejahteraan hewan. Banyaknya organisasi kemasyarakatan yang terbentuk di Provinsi Bali bisa terjadi karena adanya dua fenomena dan latar belakang, yaitu (1) akibat hubungan atau afiliasi organisasi kemasyarakatan dengan parpol (partai politik) atau penguasa (memaksa anggota organisasi kemasyarakatan memiliki keterikatan dengan kekuasaan partai atau tokoh masyarakat tertentu) dan (2) lahir dari kelompok atau crowd yang mengatasnamakan kekuasaan atas sebuah kawasan atau daerah (memaksa anggota organisasi kemasyarakatan memiliki keterikatan dengan kawasan dan anggota kelompok tersebut) (Camidi, 2013). Anggota kelompok yang memiliki keterikatan kuat antar anggota kelompoknya akan menimbulkan suatu rasa fanatisme terhadap kelompoknya. Menurut Soeroso (2008), fanatisme merupakan terjalinnya keterikatan yang kuat antara anggota kelompok dengan kelompoknya sekaligus membedakan dirinya dengan kelompok lain.

Menurut Robles (2013), fanatisme digambarkan sebagai suatu kepatuhan penuh gairah tanpa syarat, antusiasme yang berlebihan terhadap suatu hal tertentu, keras kepala, tanpa pandang bulu atau menggunakan cara-cara dengan kekerasan. Robles (2013) juga menambahkan bahwa fanatisme ditandai dengan adanya pemikiran dogmatis, tidak memiliki toleransi terhadap perbedaan dan keinginan untuk memaksakan pandangan secara sepihak, rasa harga diri meningkat dan merasa berkuasa.

Belakangan ini terjadi beberapa kasus kekerasan yang dilakukan oleh sejumlah organisasi kemasyarakatan di Bali sehingga menimbulkan keresahan pada masyarakat. Kasus pertama yang mendapat perhatian dari peneliti adalah bentrok antara anggota organisasi kemasyarakatan $\mathrm{X}$ dengan anggota organisasi kemasyarakatan $\mathrm{Y}$ yang terjadi pada tanggal 23 Desember 2012 di Padangsambian, Denpasar. Bentrokan tersebut terjadi karena anggota organisasi kemasyarakatan $\mathrm{Y}$ merasa lahannya direbut oleh anggota organisasi kemasyarakatan $\mathrm{X}$ sehingga bangunan posko dari organisasi kemasyarakatan $\mathrm{X}$ yang berada di Padangsambian dibakar oleh anggota organisasi kemasyarakatan $\mathrm{Y}$ bersamaan dengan dua unit mobil dan delapan unit sepeda motor yang diparkir disekitar lokasi kejadian, sejumlah ruko yang berada disekitar lokasi pun tak lepas dari kerusakan akibat peristiwa ini (Antaranews, 2012).

Kasus kedua terjadi di desa Karamas, Gianyar pada tanggal 1 Agustus 2013, korban dalam kasus pembunuhan ini adalah GWW pemuda berusia 28 tahun seorang anggota organisasi kemasyarakatan yang ditemukan telah tewas didalam sebuah selokan, pada mayat korban ditemukan luka bacok pada hampir seluruh bagian tubuh, sedangkan pelaku pembunuhan ini adalah seorang pemuda berusia 20 tahun anggota organisasi kemasyarakatan lain yang berinisial IWS. Sebelumnya sempat terjadi kericuhan pada sebuah toko Swalayan di desa Keramas yang melibatkan GWW dan IWS, warga yang berada disekitar lokasi tidak menduga jika peristiwa kericuhan ini akan mengakibatkan jatuhnya korban jiwa, pelaku IWS sendiri sudah diamankan dan akan diproses secara hukum (Prasetya, 2013).

Kasus ketiga terjadi didalam lembaga pemasyarakatan Kerobokan, Denpasar pada tanggal 17 Desember 2015, saat 
itu para penghuni blok D yang merupakan anggota organisasi kemasyarakatan $\mathrm{X}$ yang tengah menjalani masa hukuman menyerang narapidana lain di blok $\mathrm{C}$ yang dihuni oleh anggota organisasi kemasyarakatan Z. Penyerangan tersebut dilakukan menggunakan senjata tajam dan benda tumpul sehingga mengakibatkan satu orang meninggal dunia dilokasi serta dua orang lainnya luka berat. Tidak hanya didalam, diluar lembaga pemasyarakatan telah menunggu pasukan organisasi kemasyarakatan $\mathrm{X}$ yang ingin ikut membalaskan dendam namun aksi ini berhasil diredam pihak kepolisian yang meminta mereka membubarkan diri. Ketika diperjalanan pulang setelah membubarkan diri tepatnya disekitar jalan Teuku Umar, Denpasar pasukan organisasi kemasyarakatan X melihat sekelompok orang yang sedang mengendarai sepeda motor mengenakan atribut organisasi kemasyarakatan $\mathrm{Z}$ seketika kepada sekelompok orang tersebut pasukan dari organisasi kemasyarakatan $\mathrm{X}$ ini melampiaskan kemarahan dilokasi tersebut sehingga dua orang meninggal ditempat dan dua orang lainnya luka berat hingga harus dilarikan ke rumah sakit, saat itu seketika suasana kota Denpasar jadi mencekam (Setiawan, 2015).

Kasus keempat terjadi pada tanggal 3 Juni 2016 di desa Batuan, Gianyar seorang anggota organisasi kemasyarakatan $\mathrm{X}$ yang berinisial DGA dikejar oleh 3 pria bercadar hingga akhirnya tewas ditebas, ketiga pria bercadar tersebut diketahui berinisial MD, BA dan TD, ketiga pelaku tersebut diminta membunuh korban oleh DS yang berperan sebagai perencana dalam kasus pembunuhan ini, DS sendiri mengakui jika dia yang merencanakan, menyiapkan alat hingga menyuruh MD, BA dan TD turun dari mobil untuk mengejar dan menghabisi nyawa korban DS. Menurut AKBP Waluya Sik selaku Kapolres Gianyar, motif pembunuhan DGA adalah karena DS sebagai perencana merasa sakit hati karena anggota organisasi kemasyarakatan yang di ikutinya menjadi korban saat terjadi bentrok organisasi kemasyarakatan di lembaga pemasyarakatan Kerobokan sebelumnya (Manggol, 2016).

Fakta-fakta adanya bentrokan antar organisasi kemasyarakatan tersebut tentu menyebabkan kerugian baik bagi para anggota organisasi kemasyarakatan maupun masyarakat di lingkungan sekitar tempat terjadinya bentrokan. Tindakan yang dilakukan oleh para anggota organisasi kemasyarakatan yang saling bertikai menunjukkan adanya tindakan agresi. Menurut Taylor, Peplau, \& Sears, (2009) agresi adalah setiap tindakan yang diniatkan untuk menyakiti orang lain, agresi juga dapat dikategorikan menjadi tiga bagian yang dapat dilihat dari faktor niat, yaitu (1) antisocial aggression merupakan tindakan agresif yang melanggar norma sosial yang diterima umum, (2) prosocial aggression merupakan tindakan agresif yang mendukung norma sosial yang diterima umum, (3) sanctioned aggression merupakan agresi yang dimaklumi sesuai dengan norma kelompok sosial individu (Taylor, dkk., 2009).

Berdasarkan paparan diatas peneliti menyimpulkan bahwa sebagian oknum anggota organisasi kemasyarakatan lupa terhadap fungsi atau tujuan awal didirikannya organisasi kemasyarakatan, yakni sebagai sarana untuk menyalurkan pendapat dan pikiran bagi anggota masyarakat. Kenyataannya masyarakat yang masuk ke dalam organisasi kemasyarakatan justru menimbulkan keterikatan yang kuat antar anggota kelompok sehingga menimbulkan fanatisme terhadap kelompoknya, dimana bentrokan antar organisasi kemasyarakatan merupakan suatu hasil dari keterikatan yang kuat antar anggota kelompok sehingga menimbulkan suatu perilaku yang bersifat agresi, seperti melukai orang lain dan merusak prasarana umum apabila merasa kelompoknya direndahkan atau dirugikan, oleh karena itu maka peneliti tertarik untuk melakukan penelitian dengan topik perilaku agresi dan fanatisme kelompok, yang berjudul "Hubungan fanatisme kelompok dengan perilaku agresi pada anggota organisasi kemasyarakatan". Dari latar belakang yang sudah dipaparkan, dapat dirumuskan permasalahan dalam penelitian ini yaitu, apakah terdapat hubungan fanatisme kelompok dengan perilaku agresi pada anggota organisasi kemasyarakatan Laskar Bali Koordinator lapangan Alas Kedaton.

\section{METODE PENELITIAN}

\section{Variabel Penelitian dan Definisi Operasional Variabel Penelitian}

Dalam penelitian ilmiah terdapat berbagai macam variabel seperti variabel bebas (independent), variabel tergantung (dependent), variabel pengganggu, variabel anteseden, variabel ekstra, variabel komponen, variabel moderat, variabel kontinyu, dan variabel deskrit (Sulistyo-Basuki, 2010). Dari berbagai macam variabel tersebut peneliti akan mengukur dua variabel, yakni variabel bebas dan variabel tergantung. Variabel bebas atau yang sering disebut sebagai variabel independent merupakan variabel yang memengaruhi atau menjadi sebab perubahan atau timbulnya variabel tergantung atau variabel dependent, sedangkan variabel tergantung atau yang sering disebut sebagai variabel dependent adalah variabel yang tergantung, dipengaruhi atau yang menjadi akibat karena adanya variabel bebas atau independent (Sugiyono, 2011). Adapun variabel bebas dan variabel tergantung pada penelitian ini sebagai berikut:

Variabel Tergantung

Perilaku agresi adalah sebuah tindakan melepas emosi yang biasanya diawali dengan adanya perasaan marah atau depresi kemudian perasaan tersebut berlanjut pada keinginan untuk melampiaskan dalam bentuk tertentu baik kepada orang lain maupun pada objek-objek tertentu dengan maksud merugikan/melukai serta dilakukan dengan sengaja. Variabel ini diukur dengan skala perilaku agresi yang disusun berdasarkan aspek-aspek dari Ivancevich, Konopaske dan Matteson (2006) yaitu, agresi fisik, agresi verbal, kemarahan, dan kebencian.

$\underline{\text { Variabel Bebas }}$

Fanatisme kelompok adalah antusiasme yang berlebihan dan cenderung keras kepala terhadap sesuatu hal yang dianggap benar oleh diri sendiri atau kelompok yang diikuti serta mengabaikan semua fakta yang bertentangan dengan keyakinan diri sendiri atau kelompok. Diukur menggunakan skala fanatisme kelompok yang disusun berdasarkan aspekaspek yang dikemukakan oleh Goddard (2001), dengan sedikit penyesuaian terhadap objek yang akan diukur yaitu, besarnya minat dan kecintaan terhadap kelompok, sikap pribadi terhadap kelompok, lamanya individu menekuni satu 
kelompok/organisasi dan motivasi dari keluarga.

\section{Responden}

Populasi adalah wilayah generalisasi yang terdiri dari objek atau subjek, mempunyai kualitas serta karakteristik tertentu yang akan ditetapkan oleh peneliti untuk dipelajari hingga kemudian ditarik kesimpulan (Sugiyono dalam Purwanto, 2008). Sampel adalah suatu bagian yang dipilih dengan cara tertentu untuk mewakili keseluruhan kelompok populasi (Soenarto dalam Purwanto, 2008). Setelah menentukan populasi maka peneliti akan menentukan sampel, dimana pengertian sampel adalah sebagian dari populasi yang memiliki karakteristik yang relatif sama serta dianggap dapat mewakili populasi (Azwar, 1998). Terkait dengan alasan yang telah dikemukakan pada pendahuluan, bahwa sebagian organisasi kemasyarakatan melupakan fungsi awal yakni sebagai sarana untuk menyalurkan pendapat dan pikiran bagi masyarakat namun lebih mementingkan atribut kelompok dan rasa bangga yang tinggi terhadap kelompok masing-masing sehingga rentan menimbulkan konflik, oleh sebab itu terkait rasa fanatisme yang tinggi tersebut maka peneliti menggunakan organisasi kemasyarakatan sebagai populasi dalam penelitian ini. Adapun karakteristik sampel yang akan diambil adalah subjek merupakan anggota organisasi kemasyarakatan yang sudah menjadi anggota minimal 1 tahun dan berusia antara 18 hingga 55 tahun. Metode pengambilan sampel yang akan digunakan pada penelitian ini adalah probability sampling, dimana teknik ini merupakan teknik pengambilan sampel yang memberikan peluang setara bagi setiap unsur atau anggota populasi untuk dipilih menjadi anggota sampel (Sugiyono, 2011). Sedangkan untuk teknik pengambilan sampel yang akan digunakan dalam penelitian ini adalah cluster sampling satu langkah. Cluster sampling satu langkah adalah teknik pengambilan sampel yang digunakan untuk menentukan sampel apabila populasi atau sumber data yang akan diteliti sangat luas (Sugiyono, 2011). Untuk menetapkan sampel dari populasi mana yang akan dijadikan sumber data maka pengambilan sampel akan dilakukan secara acak dan dipilih dari cluster-cluster yang ada pada populasi induk sehingga cakupan sampel akan semakin kecil sesuai kebutuhan penelitian, misalnya sebuah organisasi masyarakat di provinsi Bali memiliki tiga belas anak ranting maka keseluruhan anggota organisasi masyarakat yang ada di provinsi Bali tersebut populasinya masih sangat luas sehingga harus dikerucutkan dengan cara memilih salah satu dari tiga belas anak ranting tersebut sehingga cakupan populasi akan lebih sederhana sesuai kebutuhan, pengkerucutan inilah yang disebut dengan cluster sampling satu langkah karena hanya menyederhanakan populasi satu kali. Penggunaan teknik sampling ini bertujuan untuk memilih anggota organisasi kemasyarakatan dari kabupaten mana yang nantinya akan menjadi sampel, dimana setelah dilakukan teknik sampling terpilihlah Kabupaten Tabanan. Jumlah sampel dalam penelitian ini sebanyak 62 orang anggota organisasi kemasyarakatan dari Laskar Bali Koordinator lapangan Alas Kedaton.

\section{Tempat Penelitian}

Untuk pengambilan data dilakukan pada anggota organisasi kemasyarakatan Laskar Bali Koordinator lapangan Alas Kedaton di kabupaten Tabanan provinsi Bali.

\section{Alat Ukur}

Alat ukur pada penelitian ini menggunkan dua buah skala yaitu skala fanatisme kelompok dan skala perilaku agresi.

Skala Fanatisme Kelompok

Dalam penelitian ini variabel fanatisme kelompok akan diukur dengan menggunakan skala yang dibuat sendiri oleh peneliti dan mengacu pada aspek-aspek fanatisme menurut Goddard (2001), diantaranya adalah: Pertama, besarnya minat dan kecintaan terhadap kelompok. Fanatisme membuat individu akan mudah memotivasi diri agar mampu meningkatkan usahanya dalam mendukung kelompok. Kedua, sikap pribadi terhadap kelompok. Hal ini merupakan suatu esensi yang sangat penting karena merupakan awal dalam memulai sesuatu. Ketiga, lamanya individu menekuni satu kelompok/organisasi. Individu dalam melaksanakan sesuatu dengan perasaan bangga, penuh kecintaan serta memiliki loyalitas maka akan menjadi sesuatu yang lebih bermakna.

Skala yang digunakan untuk mengukur variabel fanatisme kelompok dalam penelitian ini, terdiri atas 20 aitem pernyataan. Masing-masing aitem terdiri atas 4 rentang pernyataan yang memiliki rentang nilai dari sangat setuju, setuju, tidak setuju sampai dengan sangat tidak setuju. Nilai uji validitas kuisioner fanatisme kelompok bergerak dari 0,231 hingga 0,621. Reliabilitas kuisioner fanatisme kelompok adalah sebesar 0,839 yang berada diatas nilai minimum 0,6 maka dapat disimpulkan bahwa skala fanatisme kelompok adalah reliabel (Siregar, 2013).

\section{Skala Perilaku Agresi}

Dalam penelitian ini variabel perilaku agresi akan diukur dengan menggunakan skala yang dibuat sendiri oleh peneliti dan mengacu pada aspek-aspek Buss dan Perry (dalam Ivancevich, Konopaske dan Matteson, 2006), terdapat empat macam agresi, yaitu: Pertama, agresi fisik adalah agresi yang dilakukan untuk melukai orang lain secara fisik. Hal ini termasuk memukul, menendang, menusuk, membakar, dan sebagainya. Kedua, agresi verbal adalah agresi yang dilakukan untuk melukai orang lain secara verbal atau menggunakan perkataan. Bila seseorang mengumpat, membentak, berdebat, mengejek, dan sebagainya, orang itu dapat dikatakan sedang melakukan agresi verbal. Ketiga, kemarahan hanya berupa perasaan dan tidak mempunyai tujuan apapun. Contoh seseorang dapat dikatakan marah apabila sedang merasa frustrasi atau tersinggung. Keempat, kebencian adalah sikap yang negatif terhadap orang lain karena penilaian sendiri yang negatif. Contohnya adalah ketika kita menaruh curiga kepada orang lain karena berperilaku sangat baik sehingga kita berpikir orang tersebut berperilaku baik karena ada yang di inginkannya dari kita.

Skala yang digunakan untuk mengukur variabel perilaku agresi dalam penelitian ini, terdiri atas 17 aitem pernyataan. Masing-masing aitem terdiri atas 4 rentang pernyataan yang memiliki rentang nilai dari sangat setuju, setuju, tidak setuju sampai dengan sangat tidak setuju. Nilai uji validitas kuisioner perilaku agresi bergerak dari 0,267 hingga 0,819. Reliabilitas 
kuisioner perilaku agresi adalah sebesar 0,917 yang berada diatas nilai minimal 0,6 maka dapat disimpulkan bahwa skala perilaku agresi adalah reliabel (Siregar, 2013).

\section{Teknik Pengumpulan Data}

Metode pengumpulan data merupakan cara yang digunakan oleh peneliti dalam mengumpulkan data. Kemudian dalam mengumpulkan data diperlukan instrumen pengumpulan data, dimana instrumen pengumpulan data adalah alat bantu yang dipilih dan digunakan oleh peneliti dalam mengumpulkan data agar pengumpulan data menjadi sistematis dan lebih mudah dipahami (Purwanto, 2008). Instrumen pengumpulan data yang digunakan dalam penelitian ini adalah kuesioner. Penyebaran kuesioner adalah cara yang dilakukan untuk mendapatkan informasi serta data yang dibutuhkan untuk penelitian ini. Terdapat dua kuesioner dalam penelitian ini, yaitu kuesioner fanatisme kelompok dan perilaku agresi.

Kuesioner yang digunakan dalam penelitian ini merupakan kuesioner yang disusun oleh peneliti. Kemudian dilakukan uji validitas dan reliabilitas dari seluruh aitem yang terdapat dalam kuesioner. Dalam kuesioner akan dicantumkan petunjuk guna menjawab kuesioner serta responden diminta untuk mencantumkan usia, inisial atau nama jika berkenan, organisasi yang diikuti serta pekerjaan. Responden diwajibkan untuk memilih salah satu dari 4 alternatif jawaban. Kuesioner yang disebarkan pada responden merupakan kuesioner dengan bentuk pertanyaan tertutup. Terdapat empat pilihan jawaban yakni: (1) sangat setuju, (2) setuju, (3) tidak setuju, dan (4) sangat tidak setuju. Proses pengumpulan data pada penelitian ini dilakukan mulai tanggal 5 Februari 2017 hingga 5 April 2017 di sekretariat Laskar Bali Koordinator lapangan Alas Kedaton, desa Kukuh, Marga. Data yang terkumpul, kemudian dilakukan skoring oleh peneliti untuk kemudian dilakukan analisis data.

\section{Teknik Analisis Data}

Analisis data adalah cara yang digunakan untuk mengolah data yang diperoleh dari penelitian sehingga didapatkan suatu kesimpulan (Hadi, 2000). Analisis data dilakukan setelah data yang diperoleh dari seluruh subjek sudah terkumpul kemudian dikelompokan berdasarkan variabel, melakukan tabulasi data, menyajikan data dari tiap variabel yang diteliti hingga melakukan perhitungan untuk menjawab masalah dan melakukan perhitungan untuk menguji hipotesis yang telah diajukan dalam penelitian ini. Sebelum melakukan uji hipotesis dilakukan uji asumsi. Dalam penelitian ini uji asumsi yang dilakukan adalah uji normalitas dan linieritas. Metode analisis data yang digunakan adalah analisis statistik korelasi Product Moment, dan jika tidak mmemenuhi uji asumsi maka akan digunakan korelasi Spearman dengan menggunakan program IBM SPSS Statistics versi 21 untuk Mac OS. Jenis data dari variabel fanatisme kelompok dan perilaku agresi adalah interval.

\section{HASIL PENELITIAN}

Sebelum melakukan uji analisis korelasi Spearman, peneliti terlebih dahulu harus memenuhi dan melakukan pengujian asumsi terhadap data penelitian, yaitu melakukan uji normalitas, uji homogenitas, dan uji linearitas.

\section{Uji Normalitas}

Uji normalitas dalam penelitian ini diuji dengan menggunakan Kolmogorov-smirnov pada program IBM SPSS Statistics versi 21 untuk Mac OS. Uji normalitas bertujuan untuk mengetahui apakah sebaran data antara variabel fanatisme kelompok dan perilaku agresi bersifat normal atau tidak. Data dikatakan memiliki distribusi yang normal apabila signifikansi lebih besar dari $0,05(\mathrm{p}>0,05)$ (Santoso, 2010). Hasil pengujian normalitas dapat dilihat pada tabel 1 (terlampir). Sebaran data variabel fanatisme kelompok memiliki nilai signifikansi dengan probabilitas sebesar $0.499(\mathrm{p}>0,05)$ sehingga sebaran data pada variabel fanatisme kelompok berdistribusi normal. Sebaran data pada variabel perilaku agresi memiliki nilai signifikansi dengan probabilitas sebesar $0.019 \quad(\mathrm{p}<0,05)$ sehingga sebaran data pada variabel perilaku agresi berdistribusi tidak normal.

\section{Uji Linearitas}

Berdasarkan hasil uji normalitas yang sudah dijelaskan pada bagian sebelumnya, data dalam penelitian ini tidak normal sehingga peneliti tidak dapat melakukan uji parametrik dan harus melakukan uji non-parametrik, sehingga peneliti memutuskan untuk tidak melakukan uji linearitas dalam penelitian ini karena sudah tidak menentukan.

\section{Kategorisasi Variabel Fanatisme Kelompok}

Diketahui mean teoritis dari fanatisme kelompok adalah 50 dan standar deviasi dari fanatisme kelompok adalah 5.847. Berikutnya kategorisasi fanatisme kelompok dapat dilihat pada tabel 2 (terlampir). Berdasarkan kategorisasi yang telah dilakukan, dapat diketahui pada tabel 2 bahwa persentase fanatisme kelompok subjek yang masuk kategori sedang adalah sebesar $1,6 \%$, yang masuk kategori tinggi adalah sebesar 56,5\% dan subjek yang masuk kategori sangat tinggi adalah sebesar $41,9 \%$. Tidak terdapat subjek pada kategori skor sangat rendah, rendah maupun sedang.

\section{Kategorisasi Variabel Perilaku Agresi}

Diketahui mean teoritis dari perilaku agresi adalah 42.5 dan standar deviasi dari perilaku agresi adalah 8.776. Berikutnya kategorisasi perilaku agresi dapat dilihat pada tabel 3 (terlampir). Berdasarkan kategorisasi yang telah dilakukan, dapat diketahui pada tabel 3 bahwa persentase perilaku agresi subjek yang masuk kategori sangat rendah adalah sebesar $16,1 \%$, kategori rendah adalah sebesar 51,6\%, kategori sedang adalah sebesar 9,7\%, kategori tinggi adalah sebesar $17,8 \%$ dan subjek yang masuk kategori sangat tinggi adalah sebesar $4,8 \%$.

\section{Uji Hipotesis}

Dalam penelitian ini, peneliti menggunakan uji korelasi Spearman untuk menguji hipotesis, dimana uji ini bisa digunakan untuk pengukuran korelasi pada statistik nonparametrik (Santoso, 2003). Sebuah variabel dapat dikatakan mempunyai hubungan yang signifikan apabila nilai probabilitas (p) memiliki nilai yang lebih kecil dari 0.005 $(\mathrm{p}<0,05)$. Uji korelasi spearman ini diolah secara komputasi 
dengan menggunakan perangkat lunak IBM SPSS Statistics versi 21 untuk Mac OS. Hasil uji korelasi Spearman dari variabel fanatisme kelompok dengan variabel perilaku agresi ini dirangkum dan dapat dilihat pada tabel 4 (terlampir). Berdasarkan hasil uji korelasi Spearman diatas, diketahui jika nilai Sig. (2 tailed) adalah 0,356, karena nilai Sig. (2 tailed) lebih besar dari $>0,05$ maka dapat disimpulkan tidak terdapat hubungan antara fanatisme kelompok dengan perilaku agresi.

\section{PEMBAHASAN DAN KESIMPULAN}

Taylor, Peplau dan Sears (2009) menyebutkan jika antagonisme kelompok akan tampak ketika anggota satu kelompok atau yang biasa disebut in-group, menunjukkan sikap dan perilaku negatif terhadap anggota kelompok lain atau yang biasa disebut out-group. Antagonisme kelompok memiliki tiga elemen yang berbeda namun saling berkaitan, secara teori yang pertama disebut stereotip, merupakan elemen kognitif yang masih sebatas keyakinan terhadap karakteristik khas dari anggota suatu kelompok, yang kedua adalah prasangka negatif (prejudice) adalah elemen afektif dimana pada tahap ini sudah ada perasaan-perasaan negatif terhadap anggota kelompok lain dan elemen yang terakhir yakni diskriminasi sudah merujuk pada perilaku yang merugikan individu karena individu tersebut adalah bagian daripada anggota kelompok tertentu (Taylor, Peplau dan Sears, 2009).

Sesuai paparan kasus yang telah peneliti bahas pada bagian pendahuluan, kasus-kasus tersebut berpengaruh besar terhadap hubungan organisasi kemasyarakatan ini dengan masyarakat itu sendiri, yang tentu saja secara langsung memengaruhi stereotip serta menimbulkan prasangka negatif kepada organisasi kemasyarakatan tersebut, sehingga akibatnya perilaku kekerasan yang dilakukan oleh beberapa oknum anggota menyebabkan masyarakat memiliki pandangan bahwa organisasi ini menyukai kekerasan dan premanisme yang tentu saja merugikan image organisasi kemasyarakatan ini secara luas sehingga berpengaruh kepada seluruh anggota.

Prasangka merupakan bagian dari antagonisme kelompok, menurut Taylor, Peplau dan Sears (2009) prasangka adalah evaluasi negatif atas suatu kelompok atau individu berdasarkan keanggotaan individu tersebut dalam suatu kelompok, selain didasarkan pada dimensi evaluatif dan afektif, prasangka juga didasarkan pada penilaian awal yang kerap kali dilakukan sebelum tahu banyak tentang karakteristik individu atau kelompok tersebut. Dalam pendekatan kognitif terhadap prasangka konsep identitas sosial adalah elemen penting didalamnya, setiap individu tentunya mencari identitas sosialnya masing-masing apabila individu sudah menemukan identitas tersebut maka akan tercipta pengkategorisasian orang-orang disekitar individu tersebut menjadi kita (in-group) dan mereka (out-groups), pengkategorisasian ini tentunya menimbulkan konsekuensi penting.

Menurut Tajfel, dkk., dalam Taylor, dkk., (2009) in-group favoutritism effect akan menyebabkan individu lebih mengevaluasi anggota kelompoknya secara lebih positif dibandingkan selain anggota kelompoknya. Dalam kasuskasus kekerasan sebelumnya yang melibatkan oknum-oknum organisasi kemasyarakatan Laskar Bali, identitas sosial inilah yang menjadi pemicu oknum-oknum tersebut terjerat kasus kekerasan yang secara umum menjadi penyebab munculnya prasangka negatif kepada organisasi kemasyarakatan Laskar Bali. Lebih khusus lagi fakta yang ditemukan oleh peneliti dalam penelitian ini menunjukkan jika prasangka kepada organisasi kemasyarakatan Laskar Bali yang didapat dari masyarakat akibat perilaku kekerasan beberapa oknum anggota terjadi karena oknum-oknum tersebut memiliki rasa fanatisme yang tinggi terhadap kelompoknya sehingga gesekan-gesekan yang terjadi dapat memicu terjadinya bentrokan dengan anggota kelompok lain dan menyebabkan antipati dari masyarakat.

Berdasarkan hasil penelitian yang telah dilakukan dan dianalisis dengan teknik uji korelasi spearman maka diketahui bahwa pengujian hipotesis untuk mengetahui adanya hubungan antara fanatisme kelompok dengan perilaku agresi pada anggota organisasi kemasyarakatan Laskar Bali Koordinator lapangan Alas Kedaton tidak dapat diterima. Hal ini dapat dilihat dari hasil koefisien korelasi antara variabel fanatisme kelompok dengan variabel perilaku agresi yang mendapatkan nilai -,119 dan terdapat tanda negatif pada koefisien korelasi sehingga dapat disimpulkan fanatisme kelompok tidak memiliki hubungan dengan perilaku agresi pada anggota organisasi kemasyarakatan Laskar Bali Koordinator lapangan Alas Kedaton. Berdasarkan hasil penelusuran literatur yang sudah peneliti lakukan, peneliti belum menemukan hasil penelitian serupa yang memiliki hasil sama dengan penelitian ini.

Terdapat satu penelitian yang mendekati hasil dari penelitian ini, dimana penelitian yang dilakukan oleh Hutama, G. G., dkk, (2015) mendapatkan hasil perilaku agresi yang sedang namun terdapat hubungan yang positif dengan variabel bebasnya, dalam penelitian ini juga mengatakan jika nilai kohesivitas yang dapat diwujudkan dalam kegiatan-kegiatan yang positif dapat menurunkan munculnya perilaku agresi dalam sebuah kelompok Hutama, G. G., dkk, (2015). Pada lingkungan organisasi kemasyarakatan Laskar Bali Koordinator lapangan Alas Kedaton yang diteliti oleh peneliti memang terdapat kegiatan yang bersifat positif, dimana organisasi kemasyarakatan ini memiliki kegiatan bakti sosial dan bedah rumah guna memperingati hari ulang tahun organisasi kemasyarakatan tersebut. Jadi hasil penelitian ini mendukung hasil dari penelitian yang dilakukan oleh Hutama, G. G., dkk, (2015) yang menyimpulkan jika kegiatan-kegiatan yang bersifat positif dapat menurunkan kecenderungan perilaku agresi.

Proses pendekatan kepada pihak otoritas organisasi kemasyarakatan Laskar Bali Koordinator lapangan Alas Kedaton peneliti juga melihat terdapat berbagai faktor lain yang mempengaruhi rendahnya tingkat kecenderungan berperilaku agresi pada anggotanya. Selain fakta tersebut peneliti juga menemukan jika konformitas merupakan faktor yang berperan besar bagi keberhasilan organisasi 
kemasyarakatan Laskar Bali koordinator lapangan Alas Kedaton dalam mengatur anggotanya agar tidak melakukan tindakan agresi. Menurut Martin dan Hewstone (2003) dalam Taylor, dkk., (2009) orang melakukan konformitas karena beberapa alasan, diantaranya ada alasan yang penting, yakni ingin melakukan hal yang benar dan ingin disukai, dimana orang lebih suka menyesuaikan diri dengan perilaku kelompok apabila mereka menganggap anggota kelompok itu benar dan apabila mereka ingin disukai oleh anggota kelompok tersebut.

Anggota organisasi kemasyarakatan Laskar Bali Koordinator lapangan Alas Kedaton melihat secara kolektif jika kelompok mereka menganggap tindak kekerasan sebagai sesuatu yang dapat mempermalukan nama kelompok serta para atasan mereka, anggapan seperti itu dapat terbentuk didalam organisasi kemasyarakatan Laskar Bali Koordinator lapangan Alas Kedaton karena pihak otoritas sudah menerapkan komunikasi yang persuasif dalam bentuk anjuran-anjuran guna mempengaruhi para anggotanya agar menjauhi tindak kekerasan disamping anjuran-anjuran tersebut pihak otoritas organisasi kemasyarakatan Laskar Bali Koordinator lapangan Alas Kedaton juga melarang keras apabila seorang anggota melakukan tindak kriminal, dimana apabila anggota mereka melakukan hal tersebut dan terproses secara hukum maka otomatis status keanggotaan oknum tersebut akan dicabut, sehingga sanksi yang sedemikian berat dapat mengontrol perilaku dari para anggota organisasi kemasyarakatan Laskar Bali Koordinator lapangan Alas Kedaton.

Adapun saran yang dapat peneliti berikan bagi peneliti selanjutnya yang tertarik untuk melakukan penelitian serupa disarankan untuk memastikan seluruh subjek sudah mengisi kuesioner dengan baik mengikuti petunjuk pengisian kuesioner serta menggunakan subjek yang lebih banyak agar data yang dihasilkan menjadi lebih baik. Disarankan pula agar penelitian selanjutnya dapat menggunakan populasi dari organisasi kemasyarakatan lain yang serupa dengan Laskar Bali guna memperluas populasi dan mempermudah pengambilan data berdasarkan jumlah subjek. Mendapat data yang baik dalam jumlah banyak untuk isu sensitif seperti ini dirasa sulit oleh peneliti, sehingga melakukan penelitian kualitatif dirasa akan sangat baik untuk medapat data yang mendalam dan mengarah kepada subjek yang memang tepat terkait isu perilaku agresi.

\section{DAFTAR PUSTAKA}

Azwar, S. (1998). Metodologi penelitian. Pustaka Pelajar: Yogyakarta.

Azwar, S. (2004). Penyusunan skala psikologi. Yogyakarta: Pustaka Belajar

Azwar, S. (2010). Dasar-dasar psikometri. Pustaka Pelajar: Yogyakarta.

Azwar, S. (2012). Reliabilitas dan validitas. Yogyakarta: Pustaka Belajar.

Chung, E., Beverland, M.B., dan Farrelly. F. (2008). Exploring consumer fanaticism: extraordinary devotion in the consumption. Advances in Consumer Research Journal. Vol. 35 .

Goddard, H. (2001). Civil religion. New York: Cambridge University Press.
Guswani, A. M., \& Kawuryan, F. (2011). Perilaku agresi pada mahasiswa ditinjau dari kematangan emosi. Jurnal Psikologi Pitutur. Vol. 1 (2).

Hadi, S. (2000). Metodologi Research. Yogyakarta: Andi.

Haryatmoko. (2003). Mencari akar fanatisme ideologi, agama, atau pemikiran. Jakarta: Ghalia Indonesia.

Hidayatullah. (1995). Sikap fanatik dalam beragama. Jakarta: Penerbit Dian Rakyat.

Hutama, G. G., Prasetya, B. \& Purnomo, J. T. (2015). Hubungan antara kohesivitas kelompok dengan perilaku agresi pada kelompok suporter panser biru semarang. Salatiga: Universitas Kristen Satya Wacana.

Isa. (13 Agustus 2013). Jumlah dan rincian ormas di Bali. Diunduh dari

www.facebook.com: www.facebook.com/britabintang/post/503027496453286.ht ml. Tanggal 5 Agustus 2014.

Ivancevich, J. M., Konopaske, R., \& Matteson, M. T. (2006). Perilaku dan manajemen organisasi. Jakarta: Erlangga.

Jannah, M., (2014). Gambaran identitas diri remaja akhir wanita yang memiliki fanatisme K-Pop di Samarinda. e-Jurnal Psikologi fakultas Ilmu Sosial dan Politik, Universitas Mulawarman. Vol. 2 (2).

Krahe, B. (2005). Perilaku agresif. Yogyakarta: Pustaka Pelajar.

Krahe, B. (2013). The social psychology of aggression: second edition. New York: Pshychology Press.

Lembaga Alkitab Indonesia. (1997). Alkitab perjanjian lama dan perjanian baru. Jakarta: Percetakan Lembaga Alkitab Indonesia.

Manggol, H, A. (3 Juni 2016). Dewa Gede Artawan tewas bersimbah darah di Batuan Bali, Laskar Bali bantah bentrok ormas. Diunduh dari www.tribunbalinews.com: http://bali.tribunnews.com/2016/06/03/dewa-gede-artawantewas-bersimbah-darah-di-batuan- bali-laskar-balibantah-bentrok-ormas?page=all. Tanggal 22 Juni 2017.

Manuaba, R, R,. (2014). Studi pendahuluan: Tujuan berdirinya organisasi kemasyarakatan. Tabanan: Tidak dipublikasikan.

Nurgiyantoro, B., Gunawan, \& Marzuki. (2009). Statistik terapan (untuk penelitian ilmu-ilmu sosial). Yogjakarta: Gadjah Mada University Press.

Pertiwi, S. A., (2013). Konformitas dan fanatisme pada remaja Korean wave (Penelitian pada komunitas Super Junior fans club ELF "ever lasting friend") di Samarinda. e-Jurnal Psikologi fakultas Ilmu Sosial dan Politik, Universitas Mulawarman. Vol. 1 (2).

Prasetya, E. (2 Agustus 2013). Bentrokan antar ormas di Bali, satu tewas dibacok. Diunduh dari www.merdeka.com: https://www.merdeka.com/peristiwa/bentrokan-antarormas-di-bali-satu-tewas-dibacok.html. Tanggal 9 Agustus 2014.

Purwanto. (2008). Metodologi penelitian kuantitatif. Yogyakarta: Pustaka Belajar.

Putri, K. R. A., (2013). Hubungan antara identitas sosial dan konformitas dengan perilaku agresi pada suporter sepakbola persisam putra samarinda. e-Jurnal Psikologi fakultas Ilmu Sosial dan Politik, Universitas Mulawarman. Vol. 1 (3).

Robles, M. U. (2013). Fanaticism in psychoanalysis. London: Karnac Book, ltd.

Resmi, S. (2007). Hubungan antara persepsi terhadap komunikasi atasan kepada bawahan.

Santoso, S. (2010). Statistik multivariat. Jakarta: PT. Gramedia.

Santoso, S. (2013). Mengatasi berbagai masalah statistik dengan SPSS versi 11.5. Jakarta: PT. Gramedia.

Sarwono, S. W., \& Meinarno, E. A. (2009). Psikologi sosial. Jakarta: Salemba Humanika. 
Setiawan, B. (18 Desember 2015). Rusuh Denpasar Baladika vs Laskar Bali, ini kronologinya. Diunduh dari www.tempo.com:

https://m.tempo.co/read/news/2015/12/18/058728981/rusuh - denpasar-baladika-vs-laskar-bali-ini-

kronologinya. Tanggal 22 Juni 2017.

Siregar, S. (2013). Metode penelitian kuantitatif: dilengkapi perbandingan perhitungan manual \& spss. Jakarta: Kencana Prenada Media Group.

Sudjana. (2003). Metoda statistika. Bandung: Tarsito.

Sugiyono, (2007). Statistika untuk penelitian. Bandung: Alfabeta.

Sugiyono. (2011). Metode penelitian kuantitatif, kualitatif dan $R \&$ $D$. Bandung: Alfabeta.

Sugiyono. (2011). Statistika untuk penelitian. Bandung: Alfabeta.

Sugiyono. (2012). Metode penelitian bisnis. Bandung: Alfabeta.

Sulistyo, B. (2010). Metode penelitian. Jakarta: Penaku.

Supratiknya, A. (2014). Pengukuran psikologis. Yogyakarta: Universitas Sanata Dharma.

Suryabrata. (1998). Psikologi pendidikan. Jakarta: PT. Raja Grafindo Persada.

Suyono. (24 Juli 2013). Ormas di Indonesia harus siap-siap Ditertibkan. Diunduh dari www.lensaindonesia.com: www.lensaindonesia.com/2013/07/24/139-957-ormas-diindonesia-harus-siap-siap-ditertibkan.html. Tanggal 7 Agustus 2014.

Taylor, S. E., Peplau, L. A., \& Sears, D. O. (2009). Psikologi sosial: edisi kedua belas. Jakarta: Kencana

Undang-Undang Republik Indonesia Nomor 17 Tahun 2013 tentang Organisasi Kemasyarakatan. 2013. Jakarta: PT. Gramedia Pustaka Utama.

Undang-Undang Republik Indonesia Nomor 8 Tahun 1985 tentang Organisasi Kemasyarakatan. 2013. Jakarta: PT. Gramedia Pustaka Utama.

Yudha, P. T., \& Christine, P., (2005). Hubungan antara kesesakan dan konsep diri dengan intensi perilaku agresi: studi pada remaja di pemukiman kumuh kelurahan Angke Jakarta Barat. Jurnal Psikologi Universitas Esa Unggul. Vol. 3 (1). 
I.B.P.R.R MANUABA \& SUPRIYADI

\section{LAMPIRAN}

Tabel 1

Hasil uji normalitas data fanatisme kelompok dan perilaku agresi

\begin{tabular}{cccc|}
\hline Skala & Kolmogorov-Smirnov & $\mathbf{p}$ & Kesimpulan \\
\hline Fanatisme Kelompok & 0.828 & 0.499 & Data nomal \\
Perilaku Agresi & 1.524 & 0.019 & Data tidak nomal \\
\hline
\end{tabular}


Tabel 2

Kategorisasi fanatisme kelompok

\begin{tabular}{lccc}
\hline \multicolumn{1}{c}{ Rentang Nilai } & Kategori & Jumlah & Persentase \\
\hline$\leq 35$ & Sangat Rendah & 0 & $0 \%$ \\
$35<\mathrm{X} \leq 45$ & Rendah & 0 & $0 \%$ \\
$45<\mathrm{X} \leq 55$ & Sedang & 1 & $1.6 \%$ \\
$55<\mathrm{X} \leq 70$ & Tinggi & 35 & $56.5 \%$ \\
$70<\mathrm{X}$ & Sangat Tinggi & 26 & $41.9 \%$ \\
\hline
\end{tabular}


I.B.P.R.R MANUABA \& SUPRIYADI

Tabel 3

Kategorisasi perilaku agresi

\begin{tabular}{lccc}
\multicolumn{1}{c}{ Rentang Nilai } & Kategori & Jumlah & Persentase \\
\hline$\leq 29.75$ & Sangat Rendah & 10 & $16.1 \%$ \\
$29.75<\mathrm{X} \leq 38.25$ & Rendah & 32 & $51.6 \%$ \\
$38.25<\mathrm{X} \leq 46.75$ & Sedang & 6 & $9.7 \%$ \\
$46.75<\mathrm{X} \leq 55.25$ & Tinggi & 11 & $17.8 \%$ \\
$55.25<\mathrm{X}$ & Sangat Tinggi & 3 & $4.8 \%$ \\
\hline
\end{tabular}


HUBUNGAN FANATISME KELOMPOK DENGAN PERILAKU AGRESI

Tabel 4

Hasil uji korelasi Spearman

\begin{tabular}{cccc} 
& & Fanatisme Kelompok & Perilaku Agresi \\
\hline Fanatisme Kelompok & Spearman Correlation & 1 & -.119 \\
& Sig. (2 tailed) & & 356 \\
Perilaku Agresi & $\mathrm{N}$ & 62 & 62 \\
& Spearman Correlation & -.119 & 1 \\
& Sig. (2 tailed) & -356 & 62 \\
\hline
\end{tabular}

